\title{
Metode de genotipare a virusului hepatitic D
}

\author{
Laura Iulia Poloşanu', Olguța Diaconu', Ana Maria Buburuz², \\ Răzvan Ioan Grecu' ${ }^{3}$, Luminița Smaranda Iancu ${ }^{1}$ \\ ${ }^{1}$ Departamentul de Medicină Preventivă şi Microbiologie Interdisciplinară, Facultatea de Medicină \\ Generală, Universitatea de Medicină şi Farmacie „Grigore T. Popa“, Iaşi, România \\ ${ }^{2}$ Departamentul de Medicină Internă, Facultatea de Medicină Generală, \\ Universitatea de Medicină şi Farmacie „Grigore T. Popa“, Iaşi, România \\ ${ }^{3}$ Departamentul de Asistenţă Primară a Stării de Sănătate şi Epidemiologie, Facultatea de Medicină \\ Generală, Universitatea de Medicină şi Farmacie „Grigore T. Popa“, Iaşi, România
}

\begin{abstract}
REZUMAT
Infecţia cu virusul hepatitic D (VHD) este cunoscută ca fiind una dintre infecţiile care cauzează cele mai severe forme de hepatită, având prognosticul cel mai rezervat, cu rate înalte de hepatită fulminantă şi insuficienţă hepatică. Până în prezent, au fost descrise 8 genotipuri de VHD. Având în vedere implicarea diferitelor genotipuri în evoluţia bolii hepatice, o abordare ideală a pacientului ar trebui să cuprindă şi genotiparea VHD. Acest studiu a avut drept scop identificarea metodelor de genotipare a VHD descrise până în prezent. Obiectivele au constat in: identificarea metodelor folosite în genotiparea VHD, analiza comparativă a metodelor identificate şi aprecierea celei mai fiabile metode pentru utilizarea în practica medicală.

Pentru o abordare integrativă a metodelor de genotipare VHD utilizate până în prezent, am efectuat o căutare în principalele baze de date şi am luat în considerare studii originale, peer-reviewed, realizate pe subiecţi umani. Am identificat 4 metode de genotipare descrise în diferite studii de-a lungul anilor: hibridizare, RT-LAMP (Reverse Transcription-Loop-Mediated Isothermal Amplifi-cation), PCR-RFLP (Polymerase Chain Reaction-Restriction Fragment Length Polymorphism) şi PCR urmat de secvenţiere.

Studiul poate să reprezinte un punct de plecare în stabilirea metodei standard de genotipare VHD.
\end{abstract}

Cuvinte cheie: virus hepatitic D, genotipare, diagnostic

\section{INTRODUCERE}

Infecția cu virusul hepatitic D (VHD) este cunoscută ca fiind una dintre infecțiile care cauzează cele mai severe forme de hepatită, având prognosticul cel mai rezervat, cu rate înalte de hepatită fulminantă şi insuficiență hepatică (1). Odată cu descoperirea virusului Delta în 1977 de către Rizzetto, au apărut diferite controverse în legătură cu modul de acțiune al acestui virus (2). În prezent, nu există un tratament specific împotriva infecției VHD, terapia bazată pe interferon fiind singura armă utilizată pentru a lupta împotriva acestei boli $(3,4)$.
VHD este un subiect care naşte multiple controverse din cauza diversității genetice care determină evoluţii diferite ale bolii şi influențează răspunsul la tratament şi prognosticul (5). Au fost descrise până în prezent 8 genotipuri de VHD (numerotate de la 1 la 8) (6). VHD-1 este ubicuitar, în timp ce restul genotipurilor prezintă o distribuție geografică specifică: VHD-2 este întâlnit mai frecvent în Orientul îndepărtat, Japonia, Taiwan şi anumite regiuni din Rusia; genotipul 3 se regăseşte predominant în bazinul amazonian, în timp ce genotipul 4 este prezent în principal în Taiwan şi Japonia, iar genotipurile 5-8, la pacienții africani care au emi- 
grat spre Europa de Nord $(7,8)$. VHD-1 este asociat atât cu forme severe de boală, cât şi cu forme uşoare, iar VHD-2 - cu o simptomatologie clinică moderată. VHD-3 determină un tablou clinic sever, iar asocierea cu genotipul $\mathrm{F}$ al virusului hepatitic $\mathrm{B}$ (VHB) a determinat hepatită fulminantă în majoritatea cazurilor din America de Sud. În ceea ce priveşte VHD-4, există studii care au arătat că în anumite regiuni se asociază cu o progresie mai rapidă a afectării hepatice spre ciroză (9). În ultimul timp, mai multe studii au arătat că această diversitate genetică a VHD poate influența şi metodele de cuantificare a genomului ARN-VHD. Având în vedere că majoritatea tehnicilor utilizează genotipul 1 al VHD ca standard pentru validare, multe dintre metode tind să subestimeze încărcătura virală în cazul celorlalte genotipuri VHD (10).

Diagnosticul hepatitei D constă în determinarea anticorpilor totali anti-VHD care sunt prezenți atât în forma acută de boală, cât şi în cea cronică. Totuşi, există studii care au demonstrat că aceşti anticorpi pot lipsi la pacienții cu ARN-VHD prezent (11). Astfel, diagnosticul infecției VHD ar trebui să fie completat întotdeauna de determinarea şi cuantificarea ARN-VHD. Pentru aceasta, au fost descrise de-a lungul timpului diverse metode de identificare a genomului VHD, unele mai rapide, altele mai specifice, altele cu un risc mai mic de contaminare (12). Este dificil de apreciat cea mai bună metodă de genotipare deoarece majoritatea tehnicilor descrise sunt tehnici in-house (realizate în propriul laborator) care folosesc protocoale diferite. Cele mai mari discrepanțe se întâlnesc în design-ul primerilor (corespunzător antigenului VHD sau regiunii ribozomale) (13), în etapele de amplificare (realizate manual sau automat, într-o singură etapă sau mai multe, folosind hibridizarea sau probe modificate TaqMan) $(14,15)$ şi în stabilirea standardului intern de calitate (ARN-VHD transcris in vitro sau plasmide ADN care conțin secvențele țintă ale VHD) $(16,17)$. Având în vedere că există atât de multe variabile care trebuie luate în considerare, implementarea unei metode standard de cuantificare a ARN sau ADNc este departe de a fi realizată. Acest aspect a fost subiectul multor controverse în ultimii ani, dezbateri care au condus la implementarea în 2013 de către Organizația Mondială a Sănătății - World Health Organization (WHO) a unui standard de control pentru VHD-1, folosit în metodele bazate pe tehnicile de amplificare a acizilor nucleici (18). Totuşi, există studii ulterioare care au arătat că tehnicile care folosesc acest standard tind să subestimeze cuantificarea ARN-VHD în cazul celorlalte genotipuri (10).

Luând în considerare implicarea diferitelor genotipuri în evoluția clinică a pacientului cu hepatită B, o abordare ideală a acestor pacienți ar trebui să fie finalizată de determinarea genotipului VHD. Astfel, în acest articol ne îndreptăm atenția spre următorul pas în diagnosticul VHD, respectiv genotiparea. La fel cum s-a observat în cuantificarea încărcăturii virale, există, de asemenea, o diversitate în tehnicile de genotipare ale VHD. În prezent, genotiparea este folosită doar în scopul cercetării. O metodă rapidă şi eficientă de genotipare care ar putea fi utilizată în practica medicală ar putea îmbunătăți managementul pacientului şi ar putea reprezenta un punct de plecare în dezvoltarea terapiilor țintă. Până în prezent, nu există metode standard de genotipare a VHD. Multe studii au descris diverse metode de identificare a genotipului VHD, dar nu se poate aprecia care metodă este mai eficientă.

\section{OBIECTIVE}

Scopul acestui studiu este de a înțelege mai bine fiecare metodă de genotipare VHD descrisă în ultimii ani. Obiectivele au fost reprezentate de: identificarea tehnicilor folosite în genotiparea VHD şi realizarea unei comparații între ele; aprecierea celei mai bune metode de genotipare şi estimarea probabilității de a fi aplicate ca metode standard în genotiparea genomului ARN-VHD.

\section{MATERIALE ŞI METODE}

\section{Strategii de căutare}

Pentru a realiza o abordare integrativă a metodelor de genotipare VHD, am efectuat o căutare amplă în principalele baze de date: PubMed, Google Scholar, Cochrane library şi Embase. În acest scop, am folosit următoarele cuvinte cheie: "HDV genotyping", "hepatitis D genotype", "RT-PCR AND HDV", "RLFP AND HDV", "direct sequencing AND HDV”, "RT-LAMP AND HDV” şi „Hybridization AND HDV". 


\section{Criterii de includere}

Pentru a identifica metodele, am luat în considerare articole originale, peer-reviewed, care descriu metode de genotipare ale VHD realizate pe subiecți umani. Nu s-au luat în considerare protocoalele de studiu, rapoartele de caz, opiniile experţilor şi studiile realizate pe animale.

\section{REZULTATE}

În acest studiu am identificat patru metode de genotipare descrise în diferite studii. Metodele sunt: hibridizarea, RT-LAMP (Reverse Transcription Loop Mediated Isothermal Amplification), PCRRFLP (Polymerase Chain Reaction-Restriction Fragment Length Polymorphism) şi PCR urmat de secvențiere (Tabelul 1).

TABELUL 1. Studiile şi metodele identificate

\begin{tabular}{|l|l|}
\hline Metode de genotipare & Studii \\
\hline PCR-RFLP & $\begin{array}{l}\text { Wu 1995 (19) } \\
\text { Mirshafiee 2009 (20) } \\
\text { Souza 2015 (21) }\end{array}$ \\
\hline Hibridizare & Sun 2004 (22) \\
\hline PCR + secvențiere directă & $\begin{array}{l}\text { Altuğlu } 2005(23) \\
\text { Shang } 2012(24) \\
\text { Coller } 2018(25)(\text { qRT-PCR on } \\
\text { automated platform) }\end{array}$ \\
\hline RT-LAMP & Wang 2012 (26) \\
\hline
\end{tabular}

\section{DISCUŢII}

Deşi vaccinarea anti-VHB poate preveni infecția cu virus Delta, infecțiile cronice VHD încă reprezintă o problemă majoră de sănătate, diagnosticul precoce fiind crucial. Markerii serologici (antigenul şi anticorpii) nu sunt suficienţi pentru un diagnostic complet. Genotiparea VHD este importantă deoarece reprezintă singurul mod prin care putem aprecia evoluția pacientului, estima răspunsul la tratament şi formula un prognostic.

Diferite metode au fost descrise de-a lungul timpului pentru a atinge acest scop, de la hibridizare, RT-LAMP la RFLP şi PCR, urmat de secvenţiere. Deşi sunt studii care analizează fiecare metodă din punct de vedere al acurateței şi aplicabilității în laboratoarele clinice, nu a fost încă publicată, până în prezent, nicio comparație între aceste metode.

Prima metodă de genotipare VHD a fost tehnica hibiridizării, descrisă de Gupta în 1989 (27). De atunci, alte 5 genotipuri au fost identificate şi au fost utilizate cel puțin 2 tehnici noi de genotipare (28). Genotiparea prin hibridizare este o metodă care foloseşte secvențe de ADN cunoscute pentru a hibridiza secvențele complementare din ADN-ul studiat, secvențe care vor fi recunoscute ulterior prin marcare fluorescentă. Această tehnică foloseşte secvențe de ADN scurte (oligonucleotide) luate dintr-o bază de date pentru a construi secvența țintă care trebuie identificată (29).

Până în prezent, nu există studii care să identifice acuratețea metodei de hibridizare în genotiparea VHD. În 1994, Gallenger şi colab. au descris o metodă de hibridizare pentru cuantificarea VHD şi nu pentru genotipare (30). În 2004, Sun şi colab. au prezentat o asociere între PCR şi hibridizare, oferind o potențială soluție pentru diagnosticul diferitelor genotipuri VHD.

Hibridizarea prezintă o specificitate bună, însă o sensibilitate scăzută, în timp ce PCR are un risc crescut de contaminare (22). $\mathrm{Cu}$ trecerea timpului, tehnicile bazate pe PCR au fost îmbunătăţite şi, în prezent, există metode PCR într-o singură etapă, cu un risc minim de contaminare şi sensibilitate şi specificitate înalte (15). În plus, Sun şi colab. au descris metoda ca fiind foarte simplă cu un raport cost-eficiență satisfăcător care foloseşte cip-uri cu gene pentru diagnosticul clinic (22). La momentul actual, nu există metode de genotipare validate pentru toate genotipurile VHD. Avantajul acestei metode este abilitatea de a identifica un număr mare de ținte omogene.

RFLP (sau polimorfismul lungimii fragmentului de restricție) este o metodă simplă de genotipare care clivează produşii obținuți prin PCR (ampliconii) folosind enzime de restricție. A fost descrisă pentru prima dată în 1995, când Wu şi colab. au folosit Xhol şi Sacll ca enzime de restricție (19). După ataşarea acestor enzime de restricţie, genomul ADNc-VHD este clivat, rezultând fragmente de diferite dimensiuni, care, odată încărcate în gelul de electroforeză, vor migra în câmp electric în funcție de greutatea moleculară. Astfel, pentru fiecare genotip VHD există un pattern caracteristic de migrare a diferitelor secvențe de ADNc.

Genotiparea prin RFLP a fost comparată cu secvenţierea directă şi s-a dovedit a fi o metodă mai eficientă pentru cele 3 genotipuri VHD existente în acel moment. Această metodă s-a dovedit a fi de ajutor în descoperirea celorlalte genotipuri mai târ- 
ziu, în 1998 (31). De asemenea, Mirshafiee şi colab. au afirmat despre această metodă că este una simplă şi fiabilă (20). Recent, în 2015, Souza şi colab. au descris o tehnică PCR-RFLP capabilă să identifice toate genotipurile VHD (21). Pentru a valida această metodă, autorul citat a comparat rezultatele cu cele obținute prin analiză filogenetică. Astfel, RFLP s-a dovedit a fi o altă metodă fiabilă, uşor de aplicat. Aceasta nu necesită marcare radioizotopică şi poate fi folosită pentru analiza mai multor probe, in studiile clinice şi epidemiologice.

PCR este metoda clasică folosită în amplificarea oricărui genom ARN sau ADN. În principiu, pentru amplificarea genomului ARN, se recomandă transcrierea în ADNc cu ajutorul unei reverstranscriptaze pentru o stabilitate mai mare a produsului analizat (18). Ulterior, genotiparea prin secvențiere directă presupune secvențierea întregului genom ARN-VHD, urmată de analiza filogenetică în care secvențe specifice din fiecare genotip sunt urmărite, identificate şi stocate în diferite bănci de gene, de exemplu, GeneBank.

În ceea ce priveşte PCR urmată de secvențiere, au fost descrise diferite metode de-a lungul anilor. În 2005, Altuglu şi colab. au folosit RT-PCR-secvenţiere aplicată unui lot de pacienți infectați cronic VHD din Turcia, afirmând, de asemenea, că este o metodă eficientă (23). Mai târziu, Shang şi colab. au propus în 2012 o tehnică bazată pe RealTime PCR, în care ampliconii au fost utilizaţi direct pentru secvențiere, evitând paşii de extracție ARN, de reverstranscripție şi electroforeză utilizați în studiul descris anterior de Altuglu şi colab. (24). Astfel, acest ultim studiu citat pare să fie o alegere mai bună în genotiparea VHD, având în vedere riscul redus de contaminare. Recent, Coller şi colab. au prezentat o metodă mult mai promițătoare în care extracția şi amplificarea sunt realizate pe o platformă automată (25).

RT-LAMP (Loop Mediated Isothermal Amplification - Amplificarea izotermică mediată prin buclă) este o altă metodă de genotipare VHD descrisă de Wang şi colab. în 2012 (26). Spre deosebire de
PCR convențional şi Real-Time PCR, această metodă se realizează în mai puține etape şi implică un echipament mai economic. Sunt necesari doar 4 primeri special construiți care recunose secvențe țintă ADN (32) şi o temperatură constantă de $65^{\circ} \mathrm{C}$ pentru 50 de minute pentru ca reacția de amplificare să aibă loc. Astfel, avantajele acestei tehnici sunt simplitatea, eficacitatea amplificării şi riscul redus de contaminare. De asemenea, această metodă necesită şi mai puțin timp (o oră) în comparație cu PCR ( 2 ore) pentru întreg procesul de analiză. În plus, oferă posibilitatea de a identifica macroscopic rezultatele. În acest studiu, Wang şi colab. au evaluat potenţialul de aplicabilitate al RT-LAMP testând sensibilitatea şi specificitatea metodei în comparaţie cu Real-Time PCR, dar parametrii exacți nu au fost calculați. Cel mai mare dezavantaj al acestei tehnici este faptul că a fost construită doar pentru a identifica genotipul 1 VHD (26). În concluzie, şi această metodă pare a fi o metodă fiabilă care necesită a fi testată şi în cazul celorlalte genotipuri VHD.

\section{CONCLUZII}

Având în vedere că toate aceste metode se bazează pe utilizarea unor standarde construite de fiecare laborator (in-house), o comparație exactă între metode este dificil de realizat. Dintre toate tehnicile prezentate, hibridizarea şi RT-LAMP ar putea constitui viitorul pentru diagnosticul rapid al genotipului VHD, în situații de urgență, în timp ce RFLP şi PCR-secvențierea par a fi metodele de bază, fiabile, care pot fi utilizate de rutină în orice laborator pentru cercetare şi diagnostic clinic. RFLP rămâne o alegere bună pentru țările subdezvoltate care nu dispun de o platformă de secvențiere. Acest studiu ar putea reprezenta un punct de plecare pentru implementarea unei metode standard de genotipare a VHD. Sunt necesare studii ulterioare pentru descrierea unui standard în genotiparea VHD şi pentru dezvoltarea unor tehnici care ar putea fi utilizate şi în practică. 